\title{
LA REPRESENTACIÓN SOCIAL COMO VINCULACIÓN ENTRE AGENTES SOCIALES Y EL ESPACIO URBANO EN EL DISTRITO CENTRAL DE BARVA, HEREDIA, COSTA RICA
}

\section{Marcela Otárola Guevara*}

Resumen: Este artículo muestra la vinculación entre agentes sociales y el espacio urbano en la comunidad de Barva, mediante la develación de representaciones sociales que priman en la mentalidad de sus habitantes y se proyectan en la configuración de la ciudad. La acción de esos agentes incide en la morfología física y simbólica de la urbe, transformándola.

Palabras clave: Mentalidad, espacio urbano, agente social, historia urbana, representación social, morfología simbólica, morfología urbana, Barva, Costa Rica.

Abstract: This article shows the link between social partners and the urban space in the community of Barva, throughthe exposure of social representations that prevail in the mentality of its inhabitants and are projected in the configuration of the city. The action of these agents affects the physical and symbolic morphology of the city, transforming it.

Keyword: Mentality, urban spaces, social agent, urban history, social representation, symbolic morphology, urban morphology, Barva, Costa Rica.

\section{Introducción}

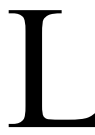

a arquitectura ha sido una disciplina muy versátil en la atención de las necesidades básicas del ser humano y se ha desarrollado como resultado de su interacción con el entorno; condición que le ha convertido en expresión de su accionar individual y colectivo. Por esta razón, analizar a lo largo

Fecha de recepción: 25/07/2015 - Fecha de aceptación: 11/10/2015

* Costarricense. Máster en Administración de Negocios por la Universidad Estatal a Distancia (2002) y licenciada en Arquitectura por la Universidad de Costa Rica (1997). Magister Scientiae en Historia Aplicada, Escuela de Historia, Universidad Nacional de Costa Rica (UNA). El presente artículo corresponde a uno de los capítulos de su tesis Una lectura polisémica de la cuidad de Barva, por la cual obtuvo la mención Summa Cum Laude. Correo electrónico: motarolag@gmail.com 
del tiempo las construcciones y su composición como conjunto en el espacio permite dilucidar el proceso de formación de un conglomerado de mujeres y hombres que trasciende la edificación misma, porque también revela su modo de producción social. Así, los poblados son concebidos como territorios donde se plasma el acto humano que ocurre, no fortuitamente, sino motivado por las ideas, valores y creencias de quienes habitan en ellos; otorgándoles una forma con dos ámbitos que son indivisibles: uno urbano y otro social. Esta premisa conduce a afirmar que, a través de la apreciación de las particularidades físicas de un asentamiento, se puede caracterizar al grupo de personas que reúne, para lo cual es necesario estudiar el contexto histórico con el objeto de comprender su devenir. Las comunidades cambian y experimentan modificaciones demográficas como consecuencia de procesos políticos, económicos y culturales. Para observar el acontecer y la territorialización de esas acciones se recurre a la historia urbana, campo especializado de la historiografía que busca elucidar y explicar las mutaciones sociohistóricas de las ciudades.

Dentro de este ámbito se circunscribe el análisis de la morfología de Barva; cantón de la provincia de Heredia en Costa Rica que, especialmente en las últimas dos décadas, ha mostrado una variación significativa en su espacio urbano, la cual se manifiesta en el rompimiento de la unidad arquitectónica que hasta los años 1980 lo distinguió. A raíz de este cambio sustancial y acelerado, se procedió a realizar una investigación para encontrar las causas de esta permuta, donde se usa, como indicio, el emplazamiento de su distrito central en el período 1945-2014.

Para ello se requirió determinar, en primera instancia, las ideas y actitudes que influyeron en la configuración de su territorio. Al respecto se encontraron las siguientes:

a) El reconocimiento de Barva como un asentamiento agropecuario consolidado y cercano al "Valle Central" costarricense. Las políticas económicas decimonónicas la definieron como una zona agropecuaria -básicamente cafetalera- y ello propició el desarrollo de infraestructura hídrica, eléctrica y vial, que la demarcaron como una región que gozó de servicios urbanos y de una ventajosa conectividad. Esta particularidad provocó, a mediados del siglo XX, desplazamientos migratorios que decantaron en la diversificación de la población y variaron el uso de la tierra: se redujo la superficie agrícola, se incrementó el sector de vivienda y se propusieron nuevas formas de convivencia; lo que, a su vez, suscitó prácticas urbanas orientadas a la exteriorización y legitimación de un concepto sobre Barva elaborado por actores nacidos en el lugar.

b) El distrito central de Barva se concibe como el principal nodo articulador de las reciprocidades del cantón. Su organización centralizada origina abundantes flujos de personas que lo definen como un espacio para el 
consumo discursivo; de allí la profusión de abundantes y variados mensajes que toman cuerpo en la apropiación del sitio, en el equipamiento urbano, en la remodelación de casas antiguas y en la introducción de edificios con un nuevo lenguaje arquitectónico.

c) La reiteración de Barva como pueblo de indios, catalogación derivada del adoctrinamiento religioso y político de los siglos XVII y XIX al que fue sometida la población como parte de una estrategia de control, promovió la disposición de la comunidad en torno a un centro hegemónico representado inicialmente solo en la iglesia; más luego también en la plaza y el edificio del cabildo -hoy municipalidad-.

d) El espacio urbano es depositario de la historia personal y comunal de los lugareños. Las narraciones de algunos personajes barveños entrevistados revelaron el simbolismo de distintos sitios del centro de Barva, basado -sustancialmente- en vivencias cotidianas que tuvieron lugar en ellos. La narración de los usos dados a edificios, calles, jardines y plazas revelaron hábitos de comportamiento provenientes de la dinámica de la red social que sobrelleva.

De este recuento cabe destacar las dos últimas consideraciones, pues su descubrimiento se debió, en gran parte, a referencias de personas del vecindario. Si bien, para la comprensión de estos actos se debió realizar un inventario y lectura de fuentes documentales -básicamente bibliográficas, censales y gráficasque reseñan eventos relevantes en la conformación de Barva, se requirió interactuar con sus habitantes para precisar sus percepciones y desentrañar el complejo universo de sus representaciones. De este modo, a partir de sus contribuciones se logró interpretar el mensaje cifrado en edificios y espacios públicos cantonales; es decir, se empleó la arquitectura como un texto que retrata los fenómenos históricos que han afectado a la ciudad.

\section{La Barva de la población barveña}

Este escrito se enfoca en el análisis de visiones y conceptos generados por informantes al realizar una pesquisa histórica acerca del pasado reciente del poblado. Su participación interesa porque, a través de sus alocuciones, se advierte el simbolismo de la urbe y los valores de los agentes que la intervienen, valga decir, sus representaciones sociales. Para alcanzar este fin, se realizó una entrevista a ocho personas de la ciudadanía barveña representativas y se platicó con otras durante el desarrollo de observaciones no participantes en el lugar de estudio.

Las ocho personas entrevistadas presentan el siguiente perfil:

- Informante A: mujer, entre 60 y 65 años de edad, nació y vive en Barva. Pensionada universitaria y miembro de la Asociación de Desarrollo de Barva en el distrito central. 
- Informante B: mujer, entre 50 y 55 años de edad, nació en Barva, vive en Heredia, comunicadora y propietaria de medios locales de difusión.

- Informante C: hombre, entre 70 y 75 años de edad, nació y vive en Barva. Microbiólogo, historiador local, líder comunal y miembro del Foro Cantonal Barveño en defensa del agua.

- Informante D: hombre, entre 45 y 50 años, nació y vive en Barva. Profesor universitario, líder comunal, miembro de la Unión Cantonal de Asociaciones y del Foro Cantonal Barveño en defensa del agua.

- Informante E: hombre, entre 65 y 70 años, nació y vive en Barva. Fotógrafo, pintor y propietario de una colección de fotos de la localidad en estudio.

- Informante F: hombre, entre 70 y 75 años, nació y vive en Barva. Pensionado, exregidor, exmiembro del Comité de Deportes local, columnista de periódicos locales y miembro del Foro Cantonal en defensa del agua.

- Informante G: hombre, entre 45 y 50 años, nació y vive en Barva. Abogado, funcionario municipal y participante en la formulación inicial del Plan Regulador para Barva.

- Informante H: hombre, entre 65 y 70 años, nació en Heredia y vive en Barva. Miembro de una de las familias cafetaleras heredianas más destacadas del siglo XX, propietario heredero de fincas agrícolas en el cantón y empresario inmobiliario.

Las personas entrevistadas fueron referenciadas como líderes o miembros de organizaciones comunales y con un gran arraigo en el cantón, todas nacidas entre los años 1940 y 1970, período en el cual aún Barva mantenía una condición urbana poco variable, que les permitía distinguir sus cambios en las postrimerías del siglo anterior. Además, otros rasgos comunes que las identifican como fuentes de interés son:

- Todas son personas adultas y han vivido en el cantón, siete nacieron en Barva y seis de ellos son hombres.

- $\quad$ Algunas son generadoras de opinión y otras influyen mediante su participación en gestiones vinculadas con el ordenamiento territorial.

- Todas han tenido injerencia en la conformación del espacio urbano por su quehacer y por su influencia en asociaciones cantonales.

- $\quad$ En su totalidad han estado ligadas, de distintas formas, a proyectos locales; han sido usuarias de los espacios públicos del distrito central y han convivido -permanente o temporalmente- en esta jurisdicción, lo que legitima en gran medida su vinculación con esta población. 
Para recoger sus apreciaciones se les interrogó en un sitio que consideraron conveniente; así, a cuatro de ellas se les visitó en su casa de habitación, a dos en sus lugares de trabajo y a otras dos en la Casa Comunal Nicolás Aguilar. Para dirigir la interlocución, se usó una guía de diálogo con preguntas abiertas sobre tres tópicos que fueron abordados desde una perspectiva histórica: antecedentes de la persona, lugares emblemáticos de Barva, tradiciones y costumbres locales. Vale mencionar que las conversaciones fueron grabadas con la venia de los sujetos interlocutores, en promedio duraron 90 minutos y fueron realizadas entre octubre de 2013 y febrero de 2014. El material de las grabaciones fue transcrito, se sintetizó en fichas y se clasificó por temas.

De sus contribuciones se obtuvo información que, por afinidad, fue reunida en cinco categorías: 1) espacios y sitios, 2) nombre de lugares, 3) apellidos, 4) nombres propios e 5) identidad local. De la lectura de las expresiones en cada uno de los grupos, se determinaron cinco tipos de discurso, según el sesgo de los relatos: a) político, b) comunal, c) histórico, d) inmobiliario y e) municipal.

\section{Referentes teóricos}

Antes de iniciar con el procesamiento y el análisis de las aportaciones de los informantes, es necesario exponer los conceptos empleados para interpretar las significaciones del corpus documental formado. Para ello se recurrió a la elaboración de un itinerario teórico que los incluye y concatena -figura 1-.

\section{Figura 1 \\ Itinerario teórico}

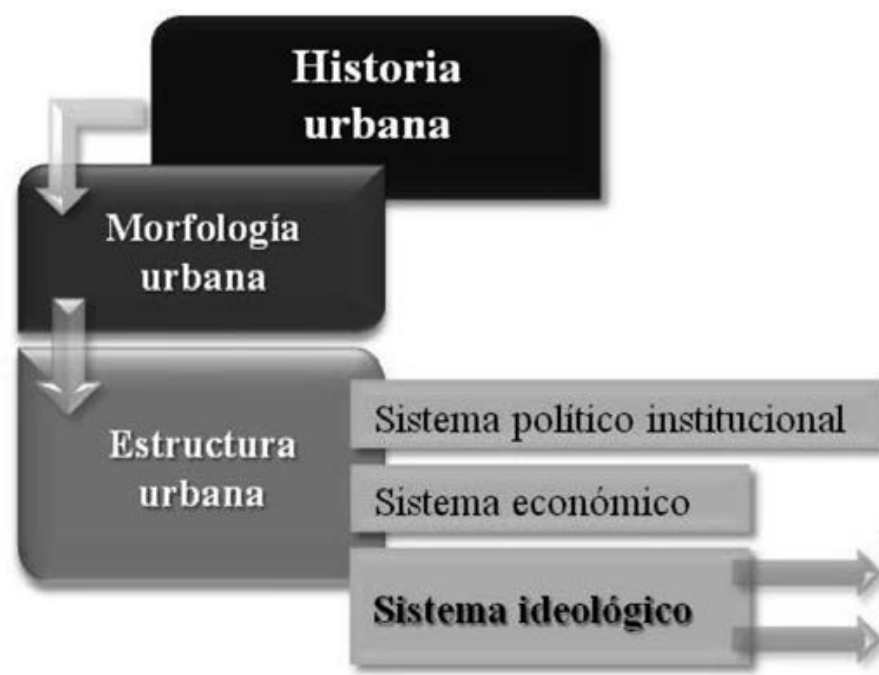

Vehículo sígnico

Representaciones sociales

Fuente: Elaboración propia. 
La historia urbana es el referente teórico abarcador. Es el campo específico que territorializa los procesos sociales, los analiza y explica su transformación enfocándose en el dónde:

\begin{abstract}
"Si algo tiene de sustantivo esa historia, creemos, es que constituye una manera de historizar esencialmente geográfica, que habla de regularidades y diferencias que se observan al analizar un proceso histórico en el paisaje urbano [...]. Dicho de otra manera, el dónde, que habitualmente en los estudios históricos se convierte en una mera ilustración circunstancial, simplemente contextual y no explicativa, es lo que acaba constituyendo la esencia misma del proceder de una historia urbana que se quiere sustantiva". ${ }^{1}$
\end{abstract}

En el dónde se materializa la urdimbre arquitectónica -edificios, parques, plazas y calles- y no es ella un fin de estudio, sino el medio para apreciar los preceptos que hay tras su apariencia. El arquitecto italiano del siglo XX, Aldo Rossi, expone esta perspectiva al indicar que en esa trama hay dos visiones “... el que considera la ciudad como el producto de los sistemas funcionales generadores de su arquitectura, y por ende del espacio urbano, y el que la considera como una estructura espacial"' 2

Interesa incorporar esta última conceptualización en el artículo porque visualiza la ciudad como una composición cuya imagen aprehensible es proyectada en el paisaje urbano. De esta proposición surgen, entonces, las siguientes interrogantes: ¿cómo está compuesta esa imagen?, o ¿cómo se puede descifrar esa construcción? En el urbanismo y la geografía hay contribuciones significativas que habilitan las respuestas.

Ambas disciplinas trabajan con el concepto de morfología urbana para explicar la forma de las poblaciones. En su acepción clásica, la noción remite al estudio de la ciudad considerando cuantitativamente su plano -la distribución del territorio-, sus edificios y usos del suelo, y logra una descripción del lugar en términos numéricos. No obstante, a partir de los años setenta del siglo anterior, el término fue debatido y con ello se generó una definición que integra la historia y la percepción ciudadana, promovida principalmente por humanistas de la geografía con interés en atender temas como "la recuperación del lugar urbano, la preocupación por el paisaje existencial o la rehabilitación de los centros históricos". 3

1 José Luis Oyón y Marta Serra Permanyer, "Historia urbana: El espacio no es inocente", Historia Contemporánea, 39 (2009): http://www.historiacontemporanea.ehu.es/s0021-con/es/../39_02.pdf (Fecha de acceso: 19 de mayo 2012).

2 Aldo Rossi, La arquitectura de la ciudad (Barcelona, España: Gustavo Gili, 1982), 65.

3 Vicente Bielza de Ory, "El tema de la morfología urbana en la historia del pensamiento geográfico", Geographicalia, 59-60 (2011): http://dialnet.unirioja.es/descarga/articulo/3937995.pdf (Fecha de acceso: 29 de enero del 2015). 
De esta manera, la morfología adquiere otra connotación y empieza a concebirse como enunciación de una comunidad. Uno de los precursores de esta visión es el geógrafo español Horacio Capel, quien declara: "la ciudad es la forma más excelsa de paisaje cultural"4; plantea que la parcelación, la edificación y los usos de suelo son variables para reconocer una realidad. También asevera que esta tarea requiere de un cuarto elemento significativo, la perspectiva histórica, por cuanto ella permite elucidar las razones de la forma, profiriéndole una explicación a la morfología.

En una reseña sobre el trabajo de Capel, el geógrafo chileno Rafael Sánchez publica esta idea:

“...pues solo en la dimensión histórica -transversal o temporal- la morfología adquiere sentido, respuesta y congruencia. La Geografía nos podrá de un hecho responder muchas interrogantes como el Qué, el Cómo, y el Dónde; pero, la historia nos abrirá las puertas del Por qué". ${ }^{5}$

Esta confirmación concede una inferencia: la morfología urbana es un punto común entre la geografía y la historia. Ella proyecta una fisonomía territorial construida a lo largo del tiempo; reconocible no solo por su composición figurativa, sino también por lo que simboliza y es compartido por quienes habitan una localidad; razón que justifica su estudio en análisis urbanos.

Barva presenta un patrón de organización centralizado en su morfología urbana. Es un conglomerado que se organiza en torno a un núcleo compuesto por la iglesia, el parque y el edificio municipal, y que constituyó el nodo embrionario de la ciudad. ${ }^{6}$ Los servicios, el comercio y las viviendas de las familias económicamente solventes se fueron levantando a su alrededor, tejiendo una red de vínculos sociales fortalecida por el conjunto de caminos que la atravesó y que deparó en un accionar de su gente, propio y diferenciador de otra población.

Se formó sobre el espacio una estructura urbana devenida de lo que el sociólogo Manuel Castells denominó "leyes estructurales y coyunturales" para referirse a normas que dan cuenta de la metamorfosis de una sociedad, sea como producto tangible o intangible. Castells, además, señala que en esta ordenación convergen tres sistemas que engloban los actos requeridos para la subsistencia humana. De uno de ellos, o de su combinación, emerge la organización social de un poblado y su especificidad; atributo que se entiende como el conjunto de

4 Rafael Sánchez, "Horacio Capel. Morfología de las ciudades. Vol.1. "Sociedad, cultura y paisaje urbano", Revista de Geografia Norte Grande, 32 (2004): http://148.215.2.11/articulo.oa?id=30003209.

5 Sánchez, 120.

6 Esta ordenación se puede apreciar al comparar fotografías aéreas del distrito central de Barva de los años 1940, 1960, 1980, 1985, 1992 y 1997 obtenidas del Archivo del Instituto Geográfico Nacional; y al cotejar mapas censales de 1962, 1972 y 1982 del Instituto Nacional de Estadística y Censos de Costa Rica.

7 Manuel Castells, La cuestión urbana (México, D.F.: Siglo XXI Editores, 1974), 141. 
rasgos propios de una localidad, que la distinguen de otras y que son consecuencia de las prácticas de sus habitantes.

El autor precisa estos sistemas como:

- $\quad$ Sistema económico. Es definido como el ámbito que “...organiza en torno a las relaciones entre la fuerza de trabajo, los medios de producción y no-trabajo...", 8 estableciendo un orden basado en la relación entre la producción y el consumo. El primero alude al individuo quien despliega su capacidad y habilidad humana para realizar tareas productivas; en tanto que el segundo se refiere a los lugares donde se consumen. A la vinculación entre ambos la llama intercambio y la precisa como la espacialización del proceso productivo.

- $\quad$ Sistema político-institucional. Es aquel donde “...el espacio se organiza en torno de dos relaciones esenciales que definen este sistema -relación de dominación-regulación y relación de integración-represión- y de los lugares determinados". 9 Plantea que hay un ordenamiento cuyo fin es mantener el control de los espacios y su correspondiente organización económica, a través de un marco normativo que legitima las reciprocidades.

- Sistema ideológico. Coherentemente con la apreciación de la ciudad como un ente ideológico, el teórico dice que hay un medio que "...organiza el espacio marcándolo con una red de signos, o contenidos ideológicos, cuya eficacia debe medirse por sus efectos sobre el conjunto de la estructura social". ${ }^{10}$ Con ello hace referencia a que, en el espacio urbano, se recrean vinculaciones de orden simbólico que transmiten ideologías y que se expresan, en sus diferentes órdenes, a través de la agencia humana.

Interesa profundizar en el sistema ideológico porque reconoce al espacio como palestra de enunciación de discursos, derivados de representaciones sociales materializadas en obras y acciones que el letrado llama formas espaciales y formas culturales ${ }^{11}$ respectivamente. Estas se encuentran imbricadas por cuanto las primeras son la expresión tangible de las segundas y, de esta manera, introduce la valoración simbólica de los territorios, edificios e intersticios urbanos, pues son alocuciones que hablan del desempeño de la estructura urbana.

Son ellas proyecciones de los pensamientos imperantes que han dictado los procedimientos que conforman la forma social y urbana de los asentamientos. Así, el espacio urbano toma otra connotación porque en él: "Existe simbólica urbana a partir de la utilización de las formas espaciales como emisores,

8 Castells, 154.

9 Ibid, 155.

10 Ibid.

11 Ibid, 258. 
retransmisores y receptores de las prácticas ideológicas generales" ${ }^{\prime 12}$ que le otorgan una función como vehículo sígnico. ${ }^{13}$

Se consideran, entonces, las ciudades como emisarios simbólicos y orientadores de los quehaceres de sus habitantes, pues comportan una matriz de significados compartidos, entrelazados y revelados físicamente. En este sentido, la arquitectura adquiere un rol como agente difusor; y es el semiólogo italiano Umberto Eco uno de los investigadores quien, con este enfoque, la ha incorporado en sus estudios.

Eco formula que los objetos arquitectónicos deben ser contemplados para elucidar la función que debe ser ejercida en ellos. Esta condición modifica su uso autómata y sugiere una reflexión sobre los significados que contiene: “...lo que permite el uso de la arquitectura -pasar, entrar, pararse, subir, salir, apoyarse, etc.-, no solamente son las funciones posibles, sino sobre todo los significados vinculados a ellas, que me predisponen para el uso funcional". ${ }^{14}$

Empero, para continuar con este abordaje, es necesario determinar qué es el significado y para ello es necesario conocer qué es el signo. Este autor lo explica, apoyándose en los aportes del arquitecto italiano Giovanni Klaus Koenig, como el estímulo que denota algo en un contexto, promueve reacciones en una entidad -individuo- y la impulsa a actuar de forma similar a sus homólogos. $\mathrm{Su}$ característica principal radica en que tiene dos dimensiones: un denotatum que alude al objeto de referencia y un significatum que remite a su significación. Esta particularidad que advierte sobre la función y el uso de los objetos arquitectónicos refleja el interés en su manejo como formas significantes, ${ }^{15}$ porque acarrean el uso de códigos, elementos necesarios para cifrar un mensaje y que deben ser analizados dentro de un contexto histórico, pues es en él donde se establece su significado.

Emprende así el espacio arquitectónico "finalidades comunicativas"16 en las que denota funcionalmente y connota simbólicamente, aplicaciones que son llamadas funciones primarias y funciones secundarias respectivamente, para referirse a la realidad física de un objeto o fenómeno y a su correspondiente significado. Estas constituyen un binomio que sustenta las formas arquitectónicas y, a lo largo de la historia, son "consumidas, sustituidas o recuperadas", ${ }^{17}$ términos que muestran el carácter mutable de los códigos y que están sujetos a resemantización, según la coyuntura en que se presenten.

De lo anterior se colige que la ciudad, como una construcción social en transformación constante, está supeditada a la reinterpretación y, por lo tanto,

12 Ibid, 259.

13 Umberto Eco, La estructura ausente (Barcelona, España: Editorial Lumen, 1978), 332.

$14 \mathrm{Ibid}, 328$.

$15 \mathrm{Ibid}, 336$.

16 Ibid, 341.

17 Ibid, 349. 
siempre está inconclusa. Esta aseveración conduce a una idea relevante: la ciudad es constantemente leída por personas usuarias quienes no se mantienen pasivas, son sensibles a la mutación y simultáneamente cambian con las urbes, de manera que entre ambas partes se establece una relación dialógica.

Estos sujetos son actores que intervienen en la configuración de la metrópolis y son llamados "sujetos urbanos" por el filósofo y semiólogo colombiano Armando Silva, quien agrega que ellos no actúan deliberadamente sino que lo hacen siguiendo contratos sociales: ${ }^{18}$ convencionalismos del orden urbano que dirigen la convivencia de un grupo humano y solventan la organización física y social de un determinado conglomerado, por lo que se infiere que son la mediación a través de la cual los individuos se relacionan con la ciudad, acciones que son llamadas "actuaciones urbanas". ${ }^{19}$

¿Qué o quién establece estos contratos sociales? Los contratos los determinan las personas como resultado de una interacción en la que intermedian sus valores, intereses e historia. Se materializan en acuerdos logrados mediante distintas estrategias -por ejemplo, la persuasión, la imposición o el adoctrinamiento- propias del quehacer del sujeto performativo, conceptualización del ser humano, formulada por Silva, para describir los actos cotidianos que afectan el ámbito urbano -espacio con características escenográficas que brinda valor expresivo a todo lo que en él se realiza-. Entonces, se puede concebir este lugar como campo de las relaciones humanas; las mismas que se fijan mediante la comunicación y cuyo esquema semeja el modelo sustantivo del lenguaje y, por tanto, existe un emisor, un receptor, un canal y un mensaje.

En este caso, es importante señalar que el canal lo conforma lo urbano -el espacio social y físico modelado por la cultura $-{ }^{20}$ del que emana el enunciado que constituye el mensaje y con el cual el ciudadano maniobra implantando un diálogo con la ciudad. El emisor y el receptor son los sujetos perfomativos y, mientras que el primero elabora el enunciado o discurso, el segundo lo aprehende, asimila y reacciona. La acción de ambas figuras se sustenta en formas colectivas que encierran procesos de reconocimiento y significación social que facultan intercambios particulares. Este simbolismo tiene gran raigambre cultural, pues deviene de cánones profundamente anclados en la comunidad, que lo instauran como una "verdad social" 21 configuradora de la visión de mundo de los individuos y guía su accionar.

Es la ciudad, entonces, una entidad -además de material y social- simbólica, donde las actuaciones urbanas son expresión de representaciones sociales,

18 Armando Silva, Imaginarios urbanos (Bogotá, Colombia: Arango Editores Ltda, 2006), 143.

19 Silva, 145.

20 Ibid, 144.

21 Ibid, 97. 
concepto de Serge Moscovici, acuñado por la investigadora Sandra Araya para referirse a:

\begin{abstract}
“...sistemas cognitivos en los que es posible reconocer la presencia de estereotipos, opiniones, creencias, valores y normas que suelen tener una orientación actitudinal positiva o negativa. Se constituyen a su vez, como sistemas de códigos, valores, lógicas clasificatorias, principios interpretativos y orientadores de las prácticas, que definen la llamada conciencia colectiva, la cual se rige con fuerza normativa en tanto instituye los límites y las posibilidades de la forma en que las mujeres y los hombres actúan en el mundo". ${ }^{22}$
\end{abstract}

Las representaciones sociales son la manifestación de un acervo o "de principios interpretativos y orientadores" ${ }^{23}$ que establecen, reproducen o modifican los hábitos de una población y se expresan en la urbe. Su naturaleza intersubjetiva promueve su estudio para comprender la cosmovisión de una colectividad y dilucidar el medio de construcción de la realidad que le circunda, donde es necesario identificar el proceso de constitución de su pensamiento, examinar sus formas de interacción y los factores que determinan sus prácticas.

\title{
Un acercamiento a las representaciones sociales de Barva
}

¿Cómo se explica el efecto de las representaciones sociales en las dinámicas sociales que modelan la estructura urbana barveña? Para responder esta pregunta fue necesario determinar primero, cuáles han sido las representaciones sociales que han primado en la mentalidad de sus habitantes y la forma cómo ellas se han proyectado en la ciudad.

Para conocer las representaciones sociales de esta localidad se procedió a indagar sobre la conformación del lugar, sus espacios simbólicos, así como las costumbres y tareas cotidianas de sus residentes oriundos del distrito central.

Ello se logró por medio de las entrevistas y conversaciones espontáneas. Del análisis de la información obtenida se fijó un "campo de la representación", es decir, la organización del "conjunto de actitudes, opiniones, imágenes, creencias, vivencias y valores presentes en una misma representación social". ${ }^{24}$

Luego, desde la premisa de que las palabras de mención recurrente expresan el posicionamiento y la preeminencia de una idea o concepto, se seleccionaron

22 Sandra Araya Umaña, Cuaderno de Ciencias Sociales 127: Las representaciones sociales. Ejes teóricos para su discusión (San José, Costa Rica: Facultad Latinoamericana de Ciencias Sociales - FLACSO, 2002), 11.

23 Araya, 11.

24 Ibid, 41. 
los vocablos más frecuentes y se procedieron a clasificar por aproximación a un tema común. Quedaron así cinco categorías:

a) Espacios y sitios -14 menciones-: incluyeron lugares o construcciones con valor simbólico para la comunidad que han sido apropiados por los habitantes mediante actividades periódicas.

b) Nombre de lugar -10 menciones-: refiere a sitios geográficamente reconocidos por los barveños y habla de los pueblos que han intervenido en la formación de su cantón.

c) Apellidos -9 menciones-: corresponden a familias influyentes de la localidad -en lo comercial y en lo político-.

d) Nombres propios -6 menciones-: rememoran figuras que son honradas por su trayectoria política o por reverencia religiosa.

e) Identidad local -10 menciones-: comprende aquellos términos que reflejan un sentimiento compartido del ser barveño.

Al comparar el peso de los vocablos que mencionaron los sujetos entrevistados, se nota que los citados con mayor frecuencia -los que tienen mayor superficie en la figura 2- fueron los nombres relacionados con espacios y sitios, identidad local y nombre de lugar. Los vocablos del primer tipo fueron mencionados por los ocho entrevistados, en tanto que los otros dos por seis de ellos. Los relacionados con apellidos fueron nombrados por siete personas; en tanto que los asociados con nombres propios, por cinco.

Cuatro informantes -A, E, F y G- se refirieron a palabras clasificadas en cuatro categorías, un par - $\mathrm{B}$ y $\mathrm{H}$ - aludió a términos en las cinco y dos solamente -C y D- hablaron sobre tres tipos. En el caso de B y H se infiere que evocaron términos en las cinco clasificaciones por su quehacer comercial -condición que les permite estar en contacto con diversos grupos de la comunidad-y por convivir entre Heredia y Barva. Esta situación hace que combinen una perspectiva interna y externa sobre la imagen del sitio: ellos identifican la mirada de barveños y la de no-barveños.

Por otra parte, los casos de C y D muestran una homogeneidad en el porcentaje de las menciones realizadas por categoría, coinciden en dos -nombre de lugar y nombres propios- y difieren en una: $\mathrm{C}$ enfatiza en identidad local y D en apellidos. Se deduce que la discrepancia proviene de su edad y su quehacer comunitario, dado que el primero supera los 70 años y ha estado vinculado a la investigación histórica del cantón; mientras que el segundo tiene 45 años y ha sido actor legal y político, de allí que realice evocaciones de apellidos que rememoran a figuras locales de esos órdenes. En cuanto a sus convergencias, se deduce que, por haber crecido y vivido en el distrito central, su reproducción social estuvo vinculada a los lugares emblemáticos y al ejercicio de prácticas urbanas 
que les identifican con Barva -nombre propio citado con bastante frecuencia por ambos-.

\section{Figura 2}

\section{Categoría de vocablos recurrentes dichos por actores sociales que} intervienen en la conformación social y urbana de Barva

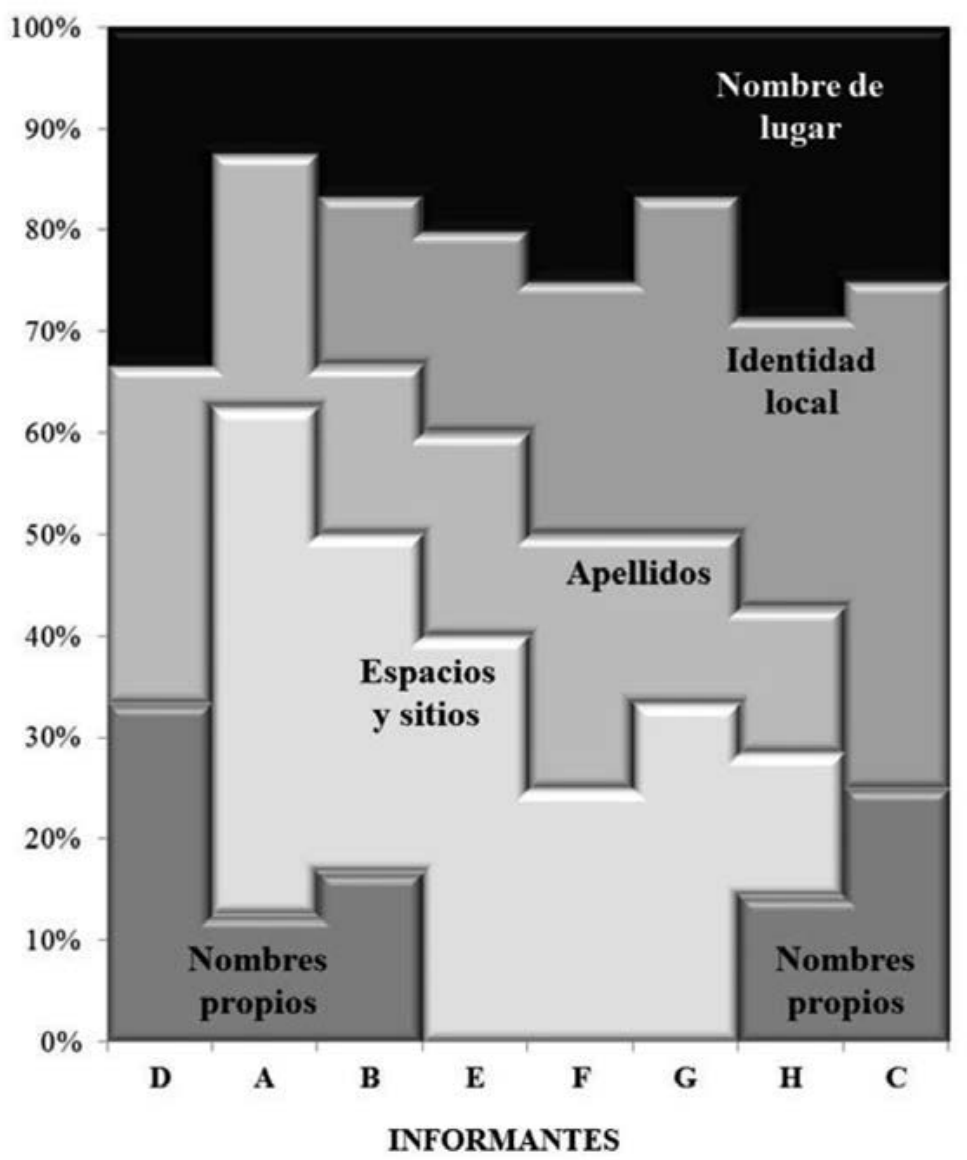

Fuente: Entrevistas a informantes de la comunidad. Elaboración propia.

Con esta información se precisó un campo de representación local y para la organización de los datos y su interpretación, se emplearon las preguntas que la investigadora Araya Umaña usa para iniciar el abordaje de esta cuestión. Con ellas se elaboró un cuadro que incorpora las interpretaciones derivadas de los hallazgos conseguidos -figura 3 -. 
Marcela Otárola Guevara

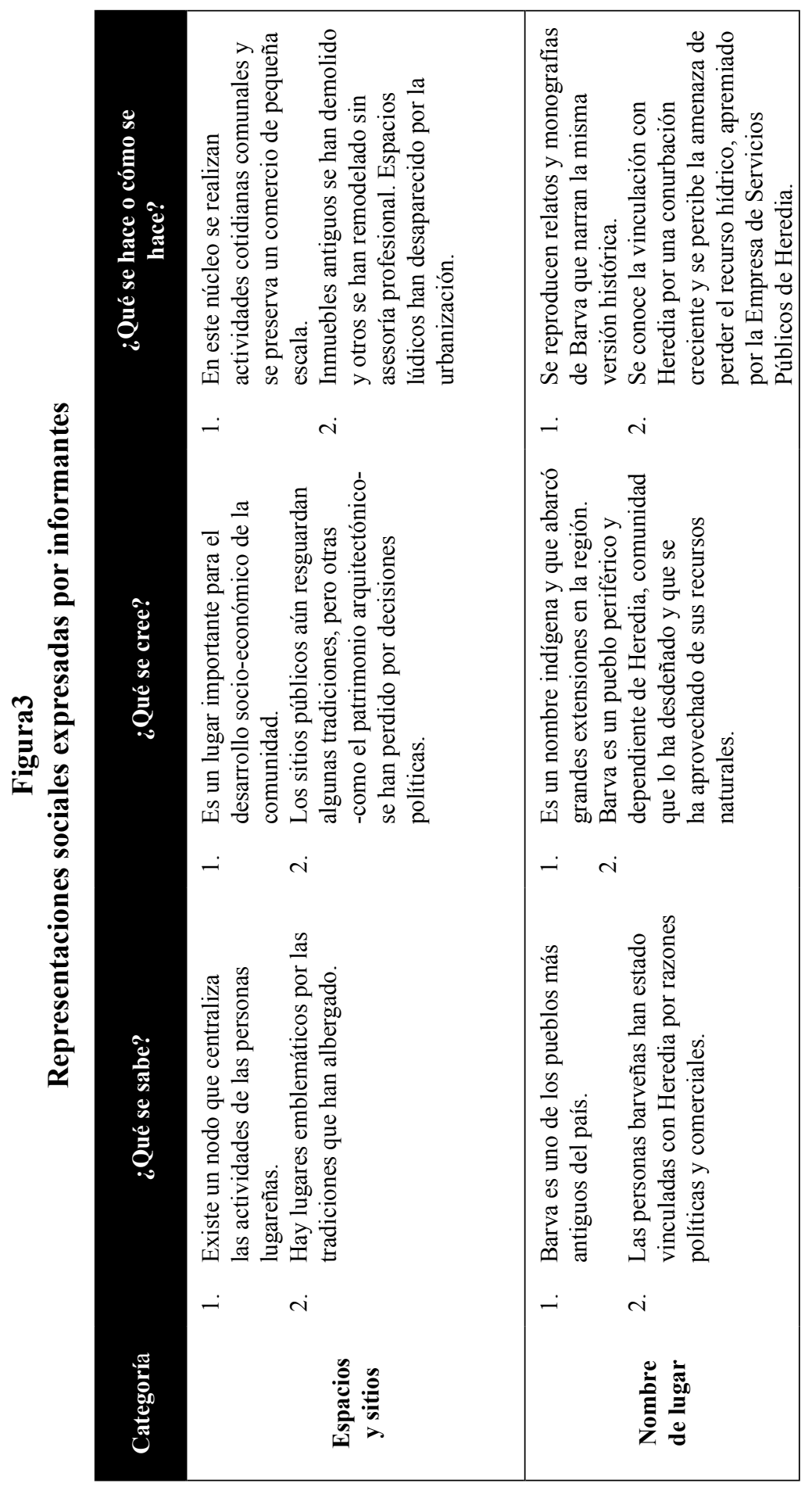




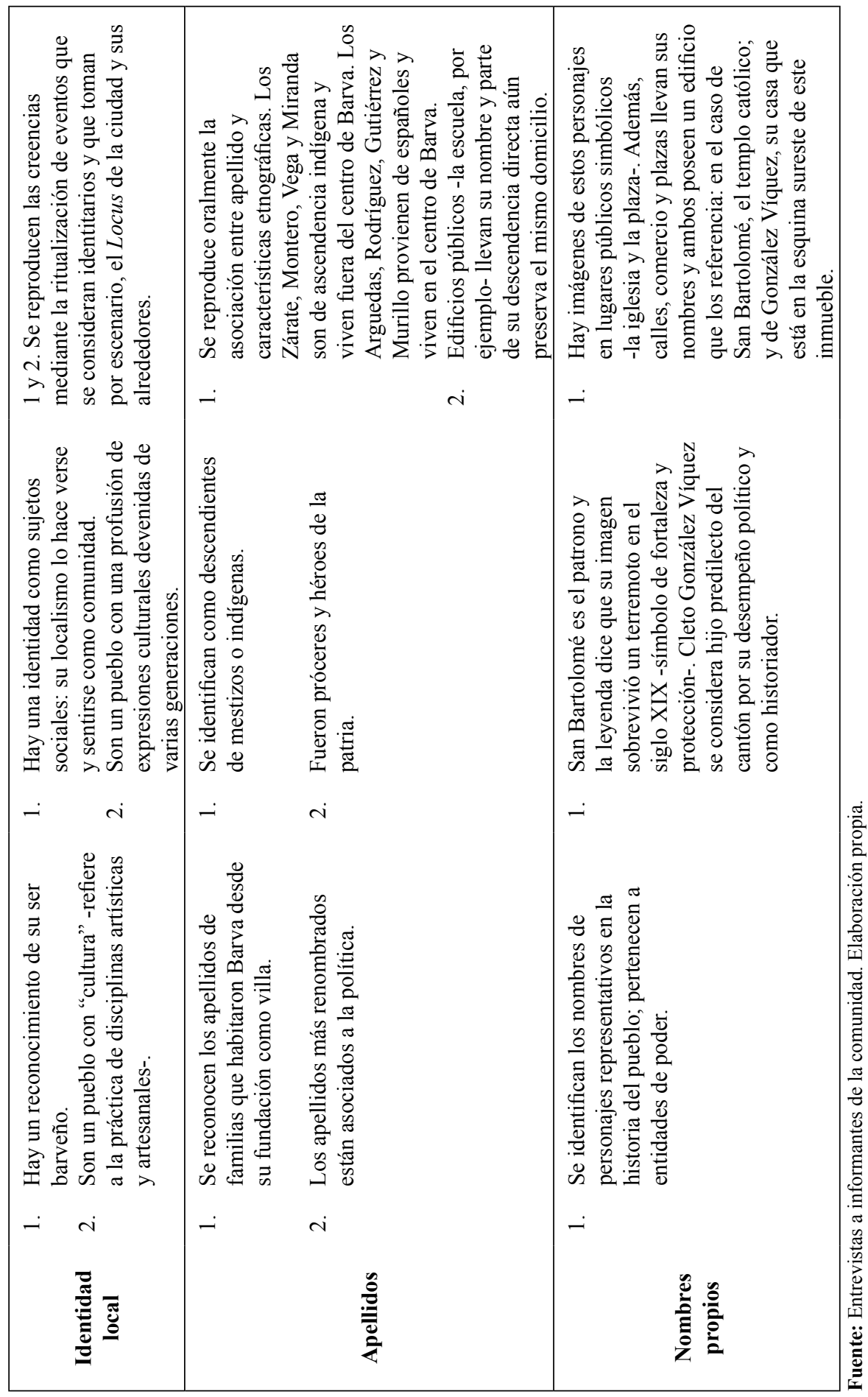


Estas revelaciones tienen un trasfondo humano subjetivo que se oculta tras la sistematización de lo reseñado. Para conocer esa dimensión se exponen algunos testimonios pertinentes, que los mismos sujetos interpelados suministraron con el fin de visibilizar la significación y apropiación que hacen del espacio urbano en el que han vivido.

En relación con nombres propios, por ejemplo, la informante B expresa la impronta espacial que deja don Cleto -el ex presidente González Víquez-:

"Después yo siento que la gente, siempre por lo menos yo como viví en ese barrio, siempre sentí mucho respeto y mucho orgullo por Cleto González, que fue el expresidente, porque la casa de don Cleto, estaba ahí a los 50 metros de mi casa, en la pura esquina de la iglesia, en la esquina sureste de la iglesia y ahí vivía una nieta, vive una nieta directa de él, de don Cleto, y entonces, como nosotros éramos del barrio, ella nos dejaba entrar a ver las fotos que ella tenía de don Cleto y nos entraba a ver la casa...". 25

Sobre espacios y sitios, la informante A nos ilustra sobre un patrón de comportamiento particular, la socialización en el ejercicio de la compra diaria que pone en valor la plaza -actual parque-:

"Yo recuerdo mi abuela vivía con nosotros cuando éramos pequeñillos, diay, en ese tiempo yo no me acuerdo si era que no había refrigeradora, pero mi abuela iba todos los días a comprar la carne y las verduras del día. Entonces estaba la verdulería, estaba la carnicería, la pulpería y la panadería, y entonces abuela iba todos los días...era un placer que ella tenía, de ir a la carnicería y a comprar las verduras que faltaban, pero duraba horas, porque se quedaba en la esquina o en la carnicería hablando o en la esquina de la plaza, hablando con las otras señoras y con los chiquillos y con todo el mundo, informándose del acontecer cotidiano, verdad, de la vida cotidiana" ${ }^{26}$

El informante $G$ exterioriza en identidad local, su criterio sobre un tema cultural que asume como valor compartido por la comunidad:

"Sinceramente le voy a decir: la cultura arquitectónica es muy pequeña para mí, se limita a la municipalidad, a la iglesia, y a dos o tres casas que quedan, nada más. Para mí el patrimonio que tiene Barva, que sí vale la pena conservarlo es el parque, la cuestión cultural...". ${ }^{27}$

25 Entrevista efectuada a informante B.

26 Entrevista efectuada a informante A.

27 Entrevista efectuada a informante G. 
Asimismo, en equivalente orden el informante $\mathrm{C}$ narra su versión sobre el poblamiento del centro de Barva como resultado de un proceso de usurpación de tierras y corrobora, a la vez, la raíz indígena de la población:

"Que los grupos indígenas, todo el grupo que se localizaba aquí en el Valle del Barva el Gran Valle de Barva -que así se llamaba- comienza a sufrir la expropiación de las tierras [...] Cuando eso sucede, los indios, los nativos muy pobres, muy pobres, muy dejados por la defensa que tenía que ocurrir en favor de ellos, en las Cortes de Cádiz, no les hacían caso, se repliegan de Río Segundo al norte. Estamos hablando de San Pablo de Barva, estamos hablando de San José de la Montaña, Birrí hasta Carrizal... se repliegan al norte, y en el centro de Barva se quedan esas familias de un corte español, mestizo español...".

Asociado a este acto de incautación en el que se reconoce como propietarios originales de las tierras barveñas a los grupos indígenas, el informante $\mathrm{D}$ destaca a Barva en nombres de lugar, al describir el alcance de su superficie antes de su constitución como cantón en el siglo XIX:

“...queriendo ser el cantón central de la provincia por historia, tuvo que ser Barva, porque francamente los territorios que ocupa hoy Heredia, eran de Barva. Santa Bárbara era de Barva, San Rafael era de Barva, es decir, el territorio de Barva llegaba hasta el Monte del Aguacate y hasta la parte de Quircot de Cartago. Ese era el gran territorio de Barva". 29

El otro lugar mencionado es Heredia, y su recordación es importante porque una parte de la conceptualización de Barva se ha basado en lo que ese sitio representa. Así lo expresa el informante $\mathrm{C}$ :

"Heredia siempre ha sido el centro, desde que nos quitaron la hegemonía [...] Aquí no había médicos, no había odontología, sí, no había nada de eso, todo estaba en Heredia. Básicamente Barva estaba compuesta por este rescoldo que quedó y que quedó separado, aislado y olvidado también. [...] Barva se convirtió como en el último (pueblo), fue el primero y el último en esta cosa de la evolución en Costa Rica y todo se centraba ahí en Heredia". ${ }^{30}$

En alusión a los apellidos, la evocación de algunos se realizó para exponer la posición de unas familias dentro de la conformación social de la comunidad

28 Entrevista efectuada a informante C.

29 Entrevista efectuada a informante D.

30 Entrevista efectuada a informante C. 
y a la vez para denotar la existencia de una sociedad estratificada en los inicios del siglo XX. Esta situación es denunciada por la informante B, al rememorar la experiencia del tradicional baile en honor al santo patrono, San Bartolomé:

“...había siempre una Comisión de fiestas muy bien conformada y en Barva si diría yo que era cierto que había una gran división -que la sigue habiendo- entre las familias tradicionales, que eran las que tenían el derecho de ir a eso y los otros, [...] porque estaban ellos, los Camacho, los Arguedas, los Solera, los Vargas, todos esos, los Bernini...o sea, había cierta gente que era la que iba a los bailes. Los otros no eran invitados, y había una división de clases muy importante...". ${ }^{31}$

Este evento se realizaba en el salón del Edificio Municipal y quienes no eran invitados participaban de los festejos en la plaza que estaba al frente del recinto en mención. El informante F así lo recuerda y cuenta:

“...en el salón municipal, había un baile de gala, que antes, de niño yo, íbamos de admiradores ahí a Los Pinos - nombre de la plaza-. Cuando entraban las parejas era algo extraordinario ver a todas las mujeres bellísimamente vestidas de vestido largo, y los hombres todos vestidos de traje entero. A ese baile nadie podía llegar ni en camisa ni en corbata ¡no! Era el baile de gala de San Bartolo. Mientras ahí se hacía ese baile, en la plaza había juego de pólvora. Alrededor de la plaza, un montón de ventas de toda clase: pejibayes, tortas, empanadas, de todo había. Otras veces estaba el baile o estaba un concierto en el atrio de la iglesia. Todo el mundo estaba en una actividad...". ${ }^{32}$

Estas declaraciones hablan de hechos que revelan perspectivas condicionantes del pensamiento social del pueblo barveño. Ellas generan arraigo, fortalecen el sentido de pertenencia y estimulan la construcción y reproducción de discursos diversos sobre la ciudad y sobre lo que allí tiene cabida.

Cotejando estas miradas y tras el análisis de las entrevistas, se detectaron cinco tipos de relatos que se diferenciaron por su contenido. Esto se encuentra intrínsecamente relacionado con la forma en que el sujeto emisor se ha involucrado con la urbe -figura 4- y recoge ideas convergentes de las personas consultadas.

31 Entrevista efectuada a informante B.

32 Entrevista efectuada a informante F. 


\section{Figura 4 \\ Tipos de discursos detectados en las entrevistas}

\begin{tabular}{|c|c|}
\hline Tipo de discurso & Contenido \\
\hline $\begin{array}{l}\text { Discurso político } \\
\text { (DP) }\end{array}$ & $\begin{array}{l}\text { Pérdida de espacios públicos para desestimular la integración } \\
\text { ciudadana, lo que favorece la pérdida de tradiciones y habilita la } \\
\text { instauración de otras costumbres. }\end{array}$ \\
\hline $\begin{array}{l}\text { Discurso comunal } \\
\text { (DC) }\end{array}$ & $\begin{array}{l}\text { El parque es un elemento articulador de la vida social -en sus } \\
\text { diferentes ámbitos- del sujeto urbano barveño y posee un valor } \\
\text { simbólico histórico porque alrededor de él se asentaron las familias } \\
\text { más antiguas y poderosas del cantón. }\end{array}$ \\
\hline $\begin{array}{l}\text { Discurso histórico } \\
\text { (DH) }\end{array}$ & $\begin{array}{l}\text { Se debe preservar la memoria histórica de forma visual, oral y } \\
\text { documental. La mayoría de los recuerdos aluden a eventos que } \\
\text { se realizaron en la plaza, la iglesia y la Gruta -espacios abiertos y } \\
\text { públicos que fueron escenarios de actividades cotidianas-. }\end{array}$ \\
\hline $\begin{array}{l}\text { Discurso inmobiliario } \\
\text { (DI) }\end{array}$ & $\begin{array}{l}\text { La preservación patrimonial es el mayor atractivo de la comunidad y } \\
\text { se debe explotar turísticamente para generar desarrollo económico. }\end{array}$ \\
\hline $\begin{array}{l}\text { Discurso municipal } \\
\text { (DM) }\end{array}$ & $\begin{array}{l}\text { El patrimonio cultural de Barva radica en sus tradiciones y en el } \\
\text { quehacer artístico y artesanal. }\end{array}$ \\
\hline
\end{tabular}

Fuente: Entrevistas a informantes de la comunidad. Elaboración propia.

$\mathrm{Al}$ asociar estos discursos con los contenidos de las categorías derivadas de los vocablos de mayor mención, se establece una correlación en la que se elucida la representación social y el mensaje que se desprende de ella. Los términos exteriorizados dejan de ser vocablos sueltos y adquieren un sentido que denota ideas sobre la ciudad -figura 5-, por ello es que se aprecia que sobre espacios y sitios los discursos otorgan gran aprecio al centro -histórico y urbano- de Barva, al considerarlo un espacio contenedor del legado cultural de la comunidad, que en nombre del lugar se expresa una forma de construcción de su idiosincrasia como alteridad de Heredia, mientras que en identidad local exaltan costumbres y actos de cohesión social que reflejan rasgos de su identidad. Todo ello denota una adhesión vecinal y una fidelidad a la tradición y a la historia local, valores preponderantes en la localidad.

En lo correspondiente a apellidos y nombres propios revelan el rol que tomaron personajes en la configuración territorial y social del distrito. En la primera tipología, se mencionan las familias que marcaron un derrotero en el trazo urbano y en las jerarquías étnicas y sociales -se afincaron alrededor de la plaza y la iglesia-, así las cuadras centrales son "personificadas" al señalarse como los asentamientos específicos de núcleos familiares -la mayoría mestiza- y se establece una estructura social donde se reconoce a la élite del pueblo. En la segunda, los nombres citados -además de referentes de agentes hegemónicos- señalan 
precisamente su localización, convirtiéndolos en puntos para la ubicación dentro de la ciudad -hitos urbanos-. De esta información se infiere la existencia de una clara división entre habitantes que se espacializó en el ordenamiento embrionario del pueblo.

\section{Figura 5}

\section{Efecto de las representaciones sociales en los discursos}

\begin{tabular}{cl}
\hline Categoría & \multicolumn{1}{c}{ Injerencia de vocablos en el discurso } \\
\hline $\begin{array}{c}\text { Espacios } \\
\text { y sitios }\end{array}$ & $\begin{array}{l}\text { Discurso político: Legitima el locus. } \\
\text { Discurso comunal: Identifica nodo articulador social. } \\
\text { Discurso histórico: Reconoce patrimonio tangible -arquitectónico- } \\
\text { e intangible -costumbres- } \\
\text { Discurso inmobiliario: Destaca el valor patrimonial de la ciudad y } \\
\text { lo concibe como motor de desarrollo. }\end{array}$ \\
\hline Nombre de lugar & $\begin{array}{l}\text { Discurso político, discurso comunal, discurso histórico: Refuerza } \\
\text { el localismo en contraposición a Heredia. }\end{array}$ \\
\hline Identidad & $\begin{array}{l}\text { Discurso comunal, discurso histórico, discurso municipal: } \\
\text { Expresión colectiva de la percepción del barveño asociada a la } \\
\text { expresión artística y artesanal. }\end{array}$ \\
\hline Local & $\begin{array}{l}\text { Discurso comunal, discurso histórico: Paralelismo entre la } \\
\text { genealogía urbana y la genealogía de familias antiguas de la } \\
\text { comunidad. }\end{array}$ \\
\hline Apellidos & $\begin{array}{l}\text { Discurso comunal, discurso histórico, discurso político: Referentes } \\
\text { políticos y religiosos que también tienen una espacialidad urbana } \\
\text { puntual -la casa de don Cleto y la iglesia-. }\end{array}$ \\
\hline
\end{tabular}

Fuente: Entrevistas a informantes de la comunidad. Elaboración propia.

Los discursos intervienen en la mentalidad y actos de la ciudadanía y se muestran en proclamas como "El patio mío era la plaza..." -Informante $\mathrm{C}$ - que hablan de una cosmovisión donde el ámbito privado se confunde con el público, $\mathrm{u}$ otra hecha por el informante $\mathrm{H}$ que refleja una extrapolación de la centralidad de la interacción humana en espacios reducidos a otros de mayor escala, considerando uno y otro orden, como partes indivisibles de un mismo universo:

\footnotetext{
“...había como un, me hace pensar que era la pulpería, creo que era de este señor Arguedas, ahí en la pura esquina, en la esquina opuesta de la iglesia, ahí. Ahí estaba, ese era como el eje central. Ahí era como un comisariato porque tenía, no era como una pulpería, tenía de todo: pulpería y cantina, y ese era como el centro de Barva". ${ }^{33}$
}

33 Entrevista efectuada a informante $\mathrm{H}$. 
Estas expresiones ratifican la existencia de un centro urbano inobjetable, de alto valor simbólico y que es expuesto como un espacio de prolongación de patrones y estilos de vida; razones por las cuales es sujeto a controlar.

Hasta hoy la regulación ha sido realizada por el gobierno local; cumplimiento reconocido por actores sociales involucrados e interesados en el tema urbano y que se descubre en el testimonio de uno de ellos, el informante G:

“...nosotros le trajimos la escritura a la municipalidad, presentamos no un proyecto de plan regulador, sino un proyecto para hacer el plan regulador real, y la municipalidad lo acogió, y el plan lo diseñó una empresa asignada, una consultora, la municipalidad contrató una empresa consultora. Hicieron los lineamientos generales del plan". ${ }^{34}$

En el relato se hace alusión al proceso de elaboración del Plan Regulador de Barva ${ }^{35}$ en el que ha participado y lo sigue haciendo el entrevistado. Él narró que la idea de generar esta herramienta fue de un grupo de vecinos y amigos -aproximadamente en el 2002-. Se reunieron y elaboraron una propuesta que fue llevada a la Municipalidad, ente encargado de desarrollar y ejecutar este tipo de protocolos, quien la acogió, la reformuló y licitó en marzo del 2004 a través del cartel "Contratación de servicios profesionales de consultoría para la elaboración del Plan Regulador para el cantón de Barva" -Licitación Pública No. 01-2004-.

Fue adjudicada a la empresa consultora Desarrollos en Ecología, Paisajismo, Planificación, Arquitectura y Turismo (DEPPAT) seis meses después, y la orden de inicio para su realización fue dada en abril del 2005. En ese mismo año el gobierno local creó la Comisión del Plan Regulador, grupo encargado de retroalimentar y dar seguimiento a las acciones de la consultora, y dispuso su integración: dos regidores titulares, el asesor legal del Concejo Municipal, un miembro del Departamento de Catastro Municipal y un asesor externo -nótese la exclusión de los ciudadanos en el proceso-. El documento fue concluido en el año 2006 y desde entonces se ha ido modificando por requerimientos de organismos consultativos -SETENA, SENARA, INVU-; ${ }^{36}$ por ello la Comisión sigue en funciones y el informante $\mathrm{G}$ se mantiene activo por su nexo laboral con el municipio.

A pesar de que aún el plan no está en vigencia, es empleado como instrumento para el ordenamiento territorial y para atender el desafío que representa

34 Entrevista efectuada a informante G.

35 Desarrollos en Ecología, Paisajismo, Planificación, Arquitectura y Turismo, Plan Regulador Urbano del Cantón de Barva de Heredia (Diagnóstico para el Plan Regulador, Municipalidad de Barva, 2006).

36 Instituciones estatales cuya gestión está relacionada con el ordenamiento territorial. SETENA (Secretaría Técnica Nacional Ambiental), SENARA (Servicio Nacional de Aguas Subterráneas Riego y Avenamiento), INVU (Instituto Nacional de Vivienda y Urbanismo). 
el aumento de la población, fenómeno que se percibe como una amenaza. Las razones para tal percepción están asociadas a su repercusión en la configuración del pueblo, reflejada en la falta de control en el uso del suelo y en la transmisión de una incertidumbre sobre la continuidad de tradiciones y costumbres del lugar. Este informante así lo declara en dos de sus intervenciones:

“...hemos externado una cierta preocupación, verdad, porque ha sido un crecimiento desordenado completamente, o sea, se han modificado usos del suelo residenciales a comerciales, sin ningún criterio". ${ }^{37}$

"Es muy poca la gente que se involucra en las actividades comunales. Obviamente si se ve participación por ejemplo en las fiestas de ocio, en las mascaradas, pero participan y en parte no, se mantienen distantes. No hay participación en cuanto a la organización o en las actividades, simplemente vienen como a turistear." 38

En síntesis, por lo hasta ahora analizado se confirma que el área de estudio es campo de expresión de representaciones sociales barveñas y, al relacionar los hallazgos, esta proposición queda expuesta. Del examen de las conversaciones y mediante la categorización de la información, se detectaron elementos simbólicos que dan sustento a ideas, valoraciones y conceptualizaciones de la ciudadanía con respecto a su entorno.

Estas fueron verbalizadas en los discursos de los sujetos informantes y se corroboraron posteriormente en imágenes fotográficas. De sus contenidos se aprecian dos claras afirmaciones sobre un espacio urbano medular definido con claridad, y que es señalado y constituido como el $l o c u s^{39}$ de la ciudad:

a) Es legitimado como sitio de memoria histórica porque representa el reservorio patrimonial de la comunidad, es un medio de articulación social porque alberga lugares simbólicos asociados a instituciones, familias y personajes emblemáticos; y se torna escenario de hábitos que se sienten, se formulan y se proyectan como rasgos identitarios -patrones de acontecimiento- que reafirman el ser local.

b) Es controlado porque se reconoce como un lugar de enunciación. Por tal motivo, ante existencia de formas de apropiación que denotan un nuevo

37 Entrevista efectuada a informante G.

$38 \mathrm{Ibid}$. El comentario se hace en alusión a la participación de migrantes en actividades tradicionales.

39 Este término, empleado en arquitectura desde los tratados clásicos de diseño del siglo XVI, es relevante en el estudio urbano porque expresa la relación que existe entre las construcciones y las vivencias humanas de una localidad, es decir, revela la vinculación del individuo con su entorno. En esta interacción intervienen afectos, ideas y percepciones hacia un territorio, lo que provoca que este se distinga dentro de un espacio indiferenciado, pues le otorga una particularidad que le hace reconocible y único. 
estilo de vida, se representa como un territorio vulnerable que requiere de políticas de regulación para su resguardo.

\section{La huellade las representaciones sociales en la forma urbana de Barva}

Al clarificar las representaciones sociales se revela aquello en lo que se cree. En esta comunidad, las creencias instituyen una idea sobre qué simboliza Barva y ello se transmite en los testimonios de habitantes que comparten un mismo discurso con sus coterráneos o coterráneas. La forma cómo perciben su localidad moldea su espacio urbano y, tras la pesquisa realizada, se pueden determinar tres aspectos sobre los que opera tal percepción: los patrones de comportamiento, los estilos de vida y los lugares simbólicos -figura 6-.

Cabe señalar que, para discernir las percepciones en una comunidad y su procedencia, se recurrió a otras fuentes de información para complementar los hallazgos obtenidos de las alocuciones; por esta razón, en esta sección se incorporan aquellos descubrimientos pertinentes que contribuyen a la comprensión y visualización de las representaciones sociales en el espacio urbano.

\section{Figura 6}

\section{Categorías, discursos y representaciones sociales en Barva}

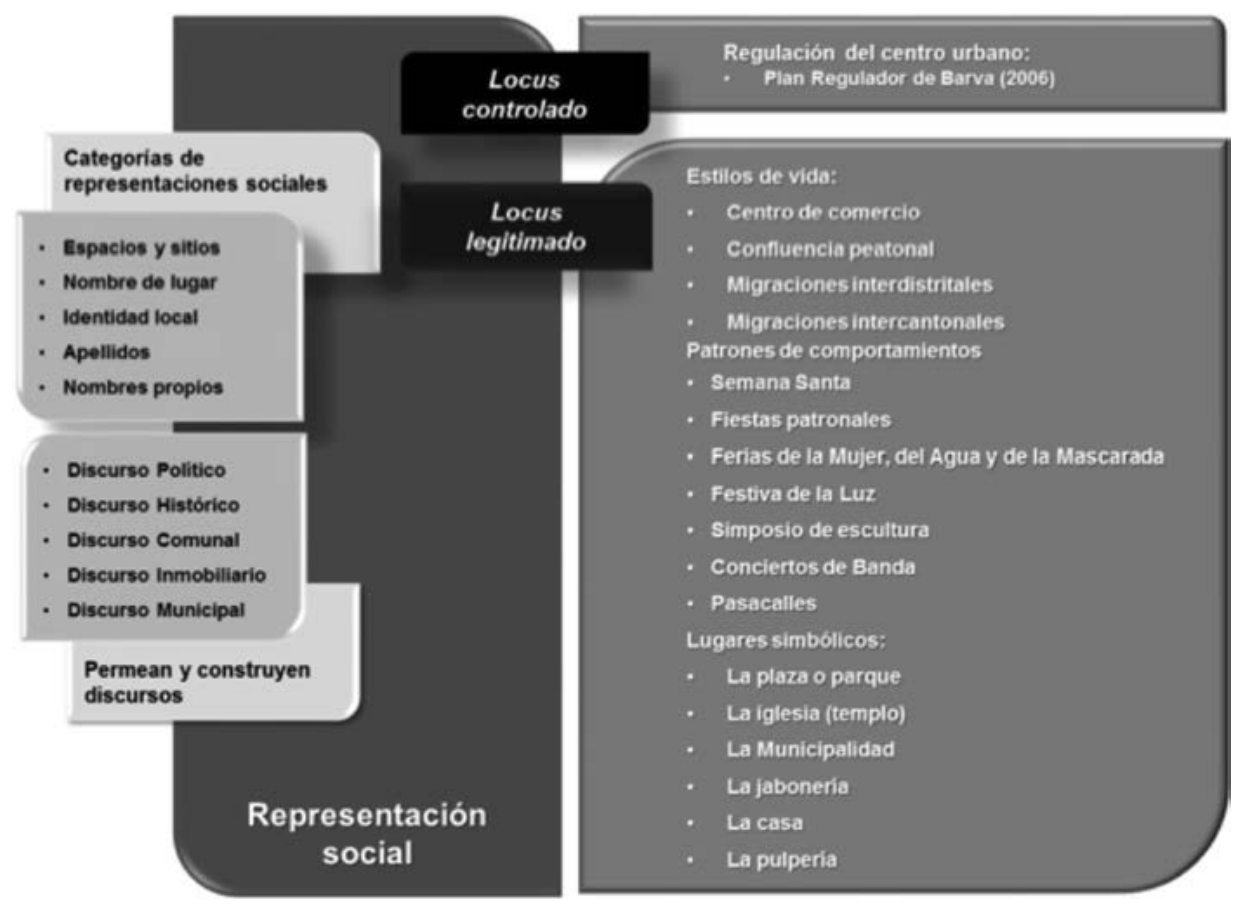

Fuente: Entrevistas a informantes de la comunidad. Elaboración propia. 
La interpretación de Barva -específicamente del área en estudio- por parte de agentes interventores en la conformación y reformulación del espacio urbano local muestra un arraigo significativo hacia el locus, compuesto por la triada iglesia-parque-edificio municipal. Su relevancia estriba en los patrones de comportamiento que admite y que corresponden a valores insertos en el pensamiento social de sus habitantes tales como: la laboriosidad comunal -satisfacción por trabajar en grupo para obtener un bien común-, la lealtad a su devenir histórico y la solidaridad entre vecinos y vecinas.

Ellos también fueron identificados en testimonios incluidos en monografías del cantón, como los hallados en Centenario de la Villa de Barba, donde se les reconoce y retrata. Un ejemplo es la narración registrada del cura Joaquín González quien, al referirse a los trabajos de construcción de la infraestructura religiosa, afirmó:

\begin{abstract}
“¿Cómo, una Parroquia de 4600 almas ha podido reunir y gastar en sus templos alrededor de 53.000 - cincuenta y tres mil colones- en menos de tres años? ¿Cómo se sostiene el culto católico y se celebran con gran solemnidad las fiestas principales de la Iglesia en un pueblo generalmente pobre? [...] Advierto de antemano que esos triunfos no se deben al Cura. -Si acaso le corresponde algo, es una módica ración en el reparto de méritos. Estos le pertenecen a la comunidad, a la feligresía que sí debe ufanarse cristianamente en sus empresas coronadas siempre con éxitos deslumbrador". ${ }^{40}$
\end{abstract}

Estos valores - que guían la acción de los sujetos urbanos- se han construido a lo largo de la historia de la comunidad, se han transmitido de una generación a otra y se desprenden, en gran medida, de prácticas instauradas por la Iglesia desde la colonia. La designación de Barva como pueblo de doctrina en esa época condujo a una administración territorial bajo la figura eclesial de la cofradía, ${ }^{41}$ entidad que, tras la conquista, cohesionó socialmente a la comunidad indígena, le implantó la fe católica como doctrina y la organizó para trabajar la tierra y así tributar a la corona española.

El escritor León Fernández compila narraciones que revalidan el rol de la entidad dentro de la inicial estructura urbana de Barva. En su libro Historia de Costa Rica durante la dominación española (1501-1821), cita el relato del Obispo Agustín Morel de Santa Cruz, donde se describen las calidades de la institución religiosa e, igualmente, registra los censos tributarios del siglo XVIII

40 Comisión de festejos, Centenario de la Villa de Barba (San José, Costa Rica: Imprenta Lehmann, 1924), 33.

41 Héctor Martínez, "Las cofradías en la Nueva España." Primer Anuario del Repositorio Institucional de la Universidad Veracruzana, 1 (1977): 45-71: http://cdigital.uv.mx/bitstream/123456789/7975/2/anuaIpag45-71.pdf (fecha de acceso: 15 febrero, 2014). 
que la muestran como un pueblo de indios laboralmente muy productivo; ${ }^{42}$ lo que sugiere, así, que el poblado de Barva adquirió una organización social sustentada en la obediencia a la autoridad y en el ejercicio de actividades agrícolas que involucraba el trabajo comunal.

La regencia la Iglesia en la localidad pervivió aún después de la Independencia de la Corona, por la preeminencia y raigambre de las celebraciones religiosas acopiadas por sus habitantes. Actividades como las de Semana Santa y las fiestas patronales de San Bartolomé acaecidas en el locus son parte de un acervo cultural vigente por décadas y reproducidas sistemáticamente por generaciones de familias lugareñas. Una revisión de álbumes fotográficos sobre Barva, disponibles en internet ${ }^{43}$ son una muestra de ello y exponen gráficamente la relación entre esos eventos, los sujetos y el territorio que los habilita.

En las imágenes se rememoran costumbres y valores en lugares urbanos, lo cual evidencia la importancia del espacio como repositorio de la memoria. Esta valoración es estimada y expresada en los discursos esclarecidos anteriormente: en el histórico y en el municipal distinguen su importancia patrimonial e identitaria; en el comunal y en el político lo destacan como punto de cohesión social; y en el inmobiliario lo visualizan como oportunidad para gestar iniciativas comerciales.

No obstante, es relevante advertir que en las fotografías también se nota que hay patrones de comportamiento que se desarrollan en espacios simbólicos no reconocidos; los no-lugares ${ }^{44}$ que, de forma improvisada, reflejan formas de convivencia derivados de la adaptación a un nuevo estilo de vida que ha propiciado la confluencia de nuevos moradores a este sector y que están convirtiendo su uso de residencial a comercial.

Esta transformación del conglomerado humano ha sido producto de la metropolización, ${ }^{45}$ proceso de urbanización en la Gran Área Metropolitana entre los años 1950 y 2005 que promovió la migración de habitantes de la provincia de San José a otros cantones. Barva fue un receptor de estas personas y, en censos demográficos del siglo XX, se aprecia su impacto en el aumento y la variabilidad en la composición de la población. Una comparación entre los registros de 1984 y el 2011 evidencian que en ese plazo -27 años- la población se incrementó en 114,76\% y el grupo de migrantes pasó de conformar el $40,4 \%$ del total a un $46,8 \%{ }^{46}$

42 León Fernández, Historia de Costa Rica durante la dominación española (1502-1821) (San José, Costa Rica: Editorial Costa Rica - ECR, 1975), 196.

43 Una gran recopilación de fotos sobre la ciudad de Barva se encuentra en el álbum del Sr. Hernán Carballo Rodríguez. Disponible en Facebook: https://www.facebook.com/hernan.carballorodriguez/photos_albums

44 Marc Augé, "No-lugares y espacio público". Disponible en: http://paisarquia.files.wordpress.com/2011/03/ auge-no-lugares-y-espacio-publico.pdf (fecha de acceso: 30 de setiembre del 2014).

45 Guillermo Carvajal, La organización del espacio urbano de la Ciudad de San José: Temas y problemas a inicios del tercer milenio (San José, Costa Rica: Editorial Librería Alma Mater, 2005), 51.

46 Información obtenida del VIII Censo Nacional de Población (1984) y del X Censo Nacional de Población y VI de Vivienda (2011), ambos realizados por la Dirección General de Estadística y Censos. Así mismo, 
Este nuevo tipo de habitante ha demandado, además de nuevos desarrollos habitacionales, bienes, servicios y un sistema de amplia conectividad vial para trasladarse, por lo que recurre a esta zona que ha identificado con facilidades de movilización y como prestataria de las transacciones y mercancías que requiere. Empero, esta población inmigrante no comparte el mismo significado del espacio urbano que los sujetos barveños locales y no han desarrollado un fuerte sentido de pertenencia hacia el lugar, porque su integración a la comunidad es nula o meramente utilitaria.

No obstante, su afluencia ha producido reciprocidades que establecen nuevos modos de coexistencia y, por esta razón, antiguas plazas y edificaciones han sido resemantizadas dentro del campo de evocación histórica, situación que ha sido advertida en el discurso histórico y en el político. En el primero se percibe en la afirmación sobre la necesidad de preservar la memoria histórica del cantón, particularmente sobre actos celebrados en espacios públicos; mientras que en el segundo se concibe como una amenaza pues, aunado al crecimiento, densificación y diversificación de la población, se considera que hay una pérdida de los espacios de socialización y, por ende, de la transmisión de sus formas tradicionales de apropiación, lo que faculta la instauración de hábitos ajenos a la idiosincrasia local.

Estas creencias han resultado en la defensa y realización de actividades tradicionales en el parque y las calles especialmente -como los pasacalles de las fiestas patronales-; y en la incorporación de imágenes características de la localidad como las máscaras, en el mobiliario urbano de gran parte de la jurisdicción.

Respecto a los lugares simbólicos reconocidos, es relevante señalar que unos coinciden con el centro urbano. De este punto irradian, a través de las carreteras, los ejes que estructuran y dan la forma física de ciudad, además de incitar a la interacción social cotidiana en ella. Sin embargo, la mención de otros recintos importantes señalados durante la investigación como la casa de don Cleto, las jabonerías y las antiguas pulperías de los Arguedas -El Mercadito y El Irisesbozan una conformación adicional que circunscribe uno de los sectores más viejos de Barva y en el que hoy se preservan algunas de las casas más antiguas de la localidad.

Tanto en fotos de colecciones privadas como en recopilaciones de libre acceso se expone esta zona y muestran, además, lugares de gran significación, pues en ellos se continúan haciendo actividades gregarias para la población. Un caso concreto es el terreno donde se construyó, en el siglo pasado, el Parque Cleto González Víquez -figura 7-, espacio donde se realizaban actos cívicos relevantes y que posteriormente fue demolido para erigir la Casa de la Cultura,

los datos fueron cotejados con los registros del Centro Centroamericano de Población, en el apartado "Información demográfica". Datos disponibles en: http://ccp.ucr.ac.cr/tasas_demograficas/tasas.html (fecha de acceso: 15 de noviembre del 2014). 
hoy sede de la Asociación Cultural Banda Sinfónica de Barva y que congrega a varios niños, niñas y jóvenes del cantón para formarse en la disciplina musical -figura 8-.

\section{Figura 7}

\section{Acto cívico en la década de 1950 en el Parque Cleto González Víquez}

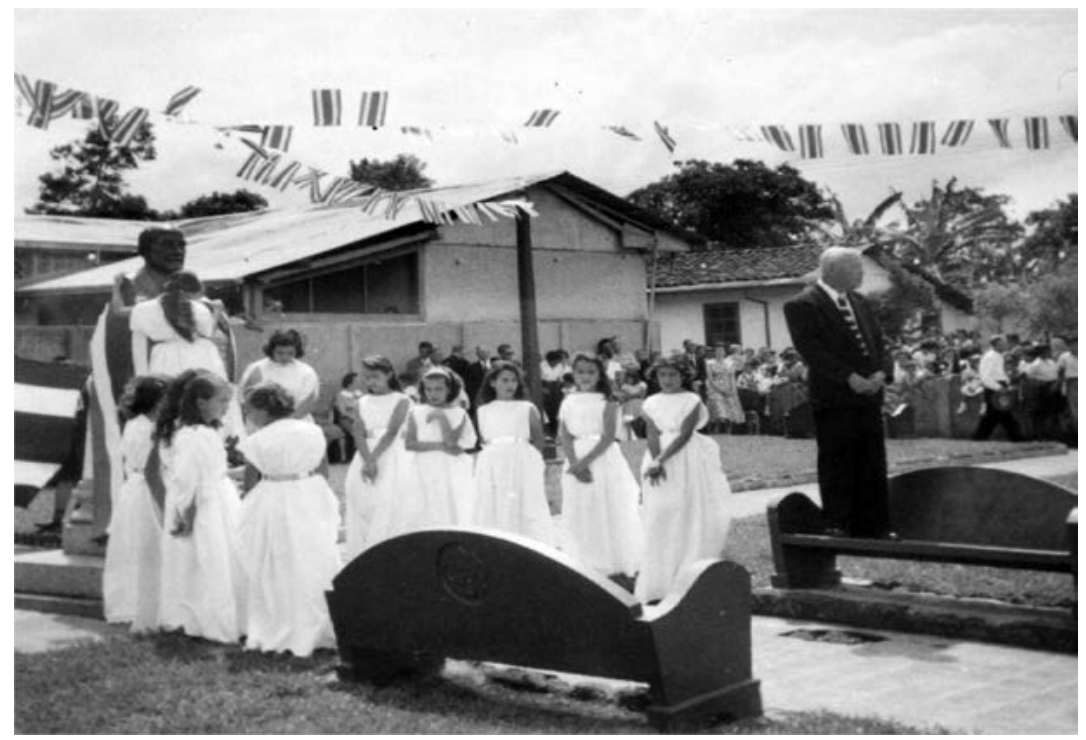

Fuente: Álbum de fotos del Sr.Hernán G. Carballo, disponible en su sitio deFacebook:https://www.facebook.com/ photo.php?fbid=190867984363846\&set=a.190206064430038.41756.100003219381696\&type=3\&theater

\section{Figura 8}

\section{Casa de la Cultura de Barva (2015), antiguo Parque Cleto González Víquez}

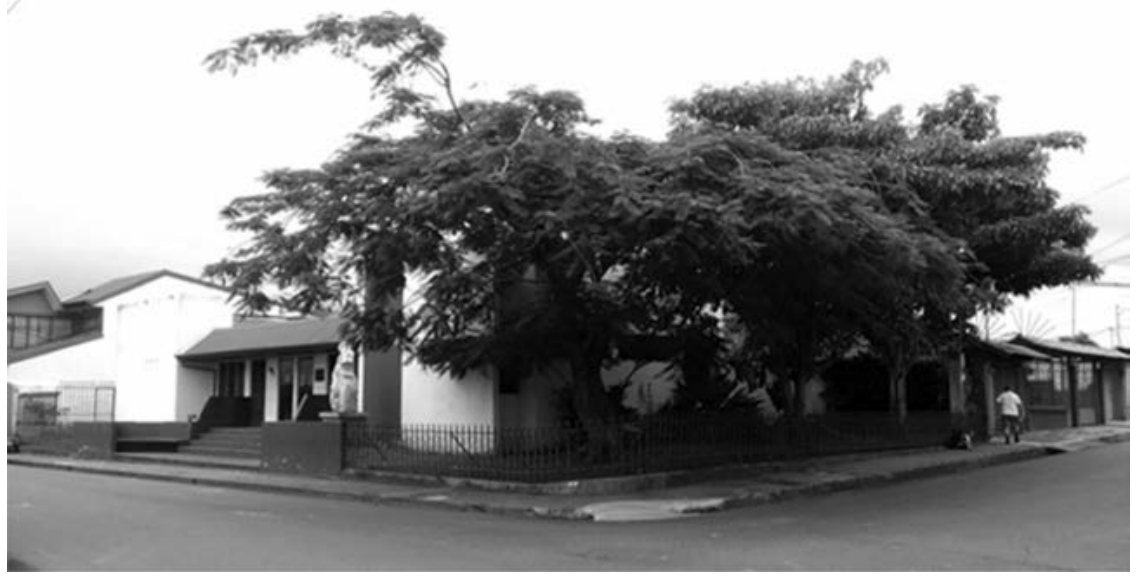

Fuente: Archivo fotográfico propio. 
La presencia de estos inmuebles delimita un sector antiguo y simbólico dentro del distrito que invita a realizar un estudio de sus estructuras arquitectónicas porque constituyen testimonios tangibles de la historia local. Diseccionar su diseño y estado generaría un acercamiento con la realidad -o realidades- que lo han transformado y; dar a conocer este cambio, concedería un mayor reconocimiento y significación patrimonial.

\section{A modo de cierre}

Las representaciones sociales modelan la morfología urbana de Barva y provienen de la experiencia de sus habitantes en procesos cotidianos de apropiación urbana establecidos desde la época colonial. Estas prácticas, de las que se encontraron escritos en crónicas españolas, también se reflejaron en historias contenidas en las entrevistas y en conversaciones informales con personas usuarias de los espacios públicos del sitio. En la lectura de sus alocuciones se observó la asociación existente entre un lugar y su función utilitaria, la que es acorde con el simbolismo que encierra y se desprende de las creencias que primaron y condujeron a la construcción, edilicia y social, de la ciudad.

Los sujetos informantes fueron seleccionados por tener edades superiores a los 45 años y por ser del lugar, con el objetivo de tratar con personas que tuvieran un vínculo socio-territorial. Este ligamen se denotó en sus narraciones donde la iglesia, la municipalidad, la casa, la pulpería, el parque y la jabonería, constituyeron los lugares con mayor mención en las conversaciones y fueron citados al evocar actividades que realizaron en distintas etapas de su vida. Actualmente, estos recintos esbozan un sector que proyecta el apego, la solidaridad y la laboriosidad de sus habitantes y se manifiesta en eventos de cohesión social como procesiones eclesiásticas, pasacalles, conciertos, exposiciones, ferias y programas deportivos que se celebran periódicamente. Su uso lúdico pervive y lo configura como el punto de encuentro de la comunidad que lo considera propio, de allí la abundancia en ellos de objetos que se consideran identitarios como esculturas, máscaras e imágenes religiosas que irrumpen como recordatorios del quehacer de algunos grupos comunales.

El sentido de pertenencia a un territorio y a una red social -establecida por consanguinidad o amistad- así como la fidelidad histórica, se advierten cuando se alude a un origen indígena y se asocia con el término Barva. Con este llaman y explican la conformación de un conglomerado -social y urbano- que se forjó como alteridad de Heredia, distinguiéndose básicamente como "pueblo de indios", proclama del discurso colonial español -siglo XVII-. Esta diferenciación entre el individuo barveño descendiente del "pueblo de indios" y el "otro no barveño", hoy se proyecta en la fuerte divisoria entre grupos oriundos e inmigrantes; lo que se acentúa en su conducta urbana, pues mientras los primeros hacen uso 
del espacio urbano para socializar; los segundos le dan un uso utilitario. Ante esta situación y por el aumento de esta población nueva, se ha promovido la transformación de viviendas y comercios de pequeña escala como las pulperías, cantinas y jabonerías en supermercados, ventas de comidas rápidas y diversos locales comerciales de franquicias nacionales; con ello se fragmenta la unidad arquitectónica de las fachadas que componen el paisaje urbano local.

Así se concluye que la imagen de la ciudad de Barva es un texto demostrativo del cambio que la afecta, circunstancia que se desprende de su naturaleza orgánica, porque es un ente tejido por seres vivos, expuestos a estímulos, que necesitan adaptarse y comunicarse. En los testimonios de la gente que la habita radican las claves para asimilar y comprender su variabilidad, reflejo de la intrínseca mutabilidad humana. 